\title{
Successful Clean Energy Technology Transitions in Emerging Economies: Learning from India, China, and Brazil
}

Radhika Khosla $^{1+*}$, Ajinkya Shrish Kamat ${ }^{2,3^{*}}$, Venkatesh Narayanamurti ${ }^{3,4}$

\begin{abstract}
Technological innovation and widespread deployment of clean-energy technologies in emerging economies are critical for a global clean energy transition. Success or failure in this endeavour will have long-term energy and carbon consequences. A fundamental question exists about whether, and how, emerging economies can accelerate clean-energy transitions, given the unprecedented scales of their impending socio-economic and infrastructure transitions, and often-underdeveloped technological innovation capabilities and supporting finances. We reflect on this question by undertaking a retrospective analysis of past and recent large-scale rapid clean-energy technology transitions in the three largest emerging economies - of light emitting diodes in India, solar photovoltaics in China, and sugarcane ethanol fuel in Brazil - each of which grew out of an unexpected set of initial technological conditions and resulted in dramatic changes to the global technological landscape. In examining how each country overcame its conventional technological lag, we discuss synthetic lessons for accelerated clean-energy transitions in emerging economy contexts: the essential role of public-sector enterprises in leveraging economies of scale; complementarities between domestic policies and global value chains; and the continued importance of domestic R\&D and academia-industry linkages. We argue that forging clean-energy pathways requires a holistic systems approach, with a shift from isolated policy approaches to a portfolio of coordinated innovation policies where demand, research and development, and manufacturing are all strategically developed.
\end{abstract}

1 Smith School of Enterprise and the Environment, University of Oxford, UK

2 Institute for Data, Systems, and Society, Massachusetts Institute of Technology, USA

3 Belfer Center for Science and International Affairs, John F. Kennedy School of Government, Harvard University, USA

4 John A. Paulson School of Engineering and Applied Sciences, Harvard University, USA

+ Corresponding author (radhika.khosla@smithschool.ox.ac.uk)

*Authors contributed equally to this work 


\section{Introduction}

Scaling up clean-energy climate solutions requires technological innovation and widespread deployment of appropriate technologies. This is critical for emerging economies ${ }^{\mathrm{i}}$, which are undergoing large socio-economic and infrastructure transitions that hold immense potential for energy system and carbon lock-in [1], [2]. Six major emerging economies - Brazil, China, India, Indonesia, Mexico, and South Africa - already account for more than one third of today's global primary energy demand, which is more than the combined energy use of the US and Europe, and has serious implications for global climate outcomes [3]. Given the scale and pace of these shifts, a fundamental question exists about whether, and how, fast-growing countries can accelerate clean-energy transitions, especially with their often-underdeveloped technological innovation capabilities and weak supporting infrastructures and finances [4]-[7]. Although research on clean energy technology transitions in developing countries has been increasing over the past fifteen years [5], [8], it is still limited and a gap remains in synthesizing lessons from different successes to inform future technological transitions in emerging economies.

We reflect on this question by undertaking a retrospective analysis of large-scale clean-energy technology transitions in the three largest emerging economies - India, China, and Brazil [9]. The transition in each country - of Light Emitting Diodes (LED) in India, solar photovoltaics (PV) in China, and sugarcane ethanol fuel in Brazil - grew out of an unexpected set of initial technological conditions, such as weak manufacturing capabilities, small market size, and high technology costs, and yet resulted in important changes to the global technological landscape. The transition in Brazil began first, a few decades ago, followed by that in China a couple of decades later. The Indian case is extremely recent, providing new empirical evidence by which to undertake a robust comparative analysis and reflect on the collective lessons. In each case, countries underwent dramatic technological transitions, involving emergence, improvements, and diffusion of low-carbon technologies, emergence of new actors and institutions in their supply chain and markets, along with shifts in policies and institutions [10]-[12]. Further, akin to the literature on technology transitions, these countries saw substantial changes in user practices, policies, and related infrastructures, which are essential for long-term, multi-dimensional, and multi-sector economy-wide transitions toward more sustainable modes of production and consumption [11]-[14].

Methodologically, we use the technological innovation systems (TIS) functional framework to compare technological transitions across these geographies and technologies [10], [15], [16]. As one of the prominent frameworks in the broader field of innovation studies, it recognizes the inherent systemic nature of innovation processes [12], [17] and is designed to study innovation processes or technology transitions in the context of a specific technology. The framework captures the dynamic nature of technology transitions in seven specific functions essential for a successful technology transition [10], [15]. In brief, these are (F1) knowledge development, (F2) knowledge diffusion, (F3) entrepreneurial experimentation, (F4) policy guidance for direction of market expansion and technology improvement (called 'guidance for search' in [10]), (F5) market formation, (F6) resource mobilization, and (F7) technology legitimation. Previously, the TIS framework has been applied to study the dynamics of technology transitions in a specific low-carbon technology in a specific country [18], [19] and also to compare transitions in a specific technology in different geographies [20], [21]. In this paper, we use the TIS functional approach as an organizing framework to compare technological transitions across geographies and technologies. For each of the seven TIS functions, we examine how each country overcame its technological lag, followed by an integrated view of the forward-looking lessons. Given our side-by-side assessment of three technologies in different parts of the energy system (electricity end use, electricity generation, and transport fuel), within different countries and governance structures, the lessons extracted are intentionally not country- or technology-specific but rather are applicable more broadly to low-carbon technologies in emerging economy contexts. 
Empirically, we assess the literature on India's LED transition, China's PV transition, and Brazil's sugarcane ethanol transition. We also draw on our own experience of working on technology innovation across countries and technologies. To capture the most relevant literature, we use Scopus to review the highest cited papers on China's PV transition and Brazil's sugarcane ethanol transition. We also reviewed additional papers which are not among the top 25 highest cited papers yet provide important additional insights. As India's LED transition is extremely recent, there is only one scholarly paper studying its dynamics [22], and we draw on additional non-academic materials and the authors professional experience of researching this case.

This Perspective is timely for three reasons. First, it provides insight for impending transitions in countries that are growing fast and in the process of making path-dependent energy technology choices [1], [2], [23]. Importantly, the energy and climate futures of these countries carry implications not just for national objectives but also for global outcomes. Second, with their scale, and rapidly growing research and select innovation capabilities, large emerging economies hold the potential to deviate from predictable technological trajectories, move beyond technological catch-up, and influence global trends [4], [7], [24]-[29]. For instance, China, India, and Brazil rank first, third, and seventh respectively in the production of renewable electricity globally [3], are among the top ten countries in terms of their national expenditure on research and development (R\&D) [30], and among the top seventeen (with India and China in the top 5) destinations for R\&D investments of the US's multinational companies [31]. Third, emerging economies need to carve their own growth pathways as the challenges facing them - ranging from multiple development imperatives, large domestic energy needs, the impacts from and urgency of addressing climate change, and working in an ever more globalized economic landscape - are distinct from what today's developed countries faced during their growth phase [1], [5], [8], [24], [26].

Next, we describe the clean energy technology transitions in India, China, and Brazil. Error: Reference source not found (placed at the end of the paper) synthesises the comparative analysis across the TIS functions for the countries. The analysis is followed by a discussion that distils the commonalities and lessons for informing future low-carbon transitions in emerging economies.

\section{Illuminating homes with LEDs in India}

The Indian case is the most recent of the three technology transitions discussed, where an unprecedented 130-fold expansion of the LED lighting market took place in merely five years (20142018). Annual sales increased from 5 million to 669 million LED bulbs in this time (Error: Reference source not found) [32]. By 2018, LEDs became the dominant lighting technology with $46 \%$ share in terms of number of bulbs sold in a year, overtaking incandescent lamps without a phase-out policy for the latter. The magnitude of LED market growth is even more striking given India's relatively weak solid-state lighting innovation system prior to 2014, which was characterized by low LED demand and few relevant manufacturing units. 


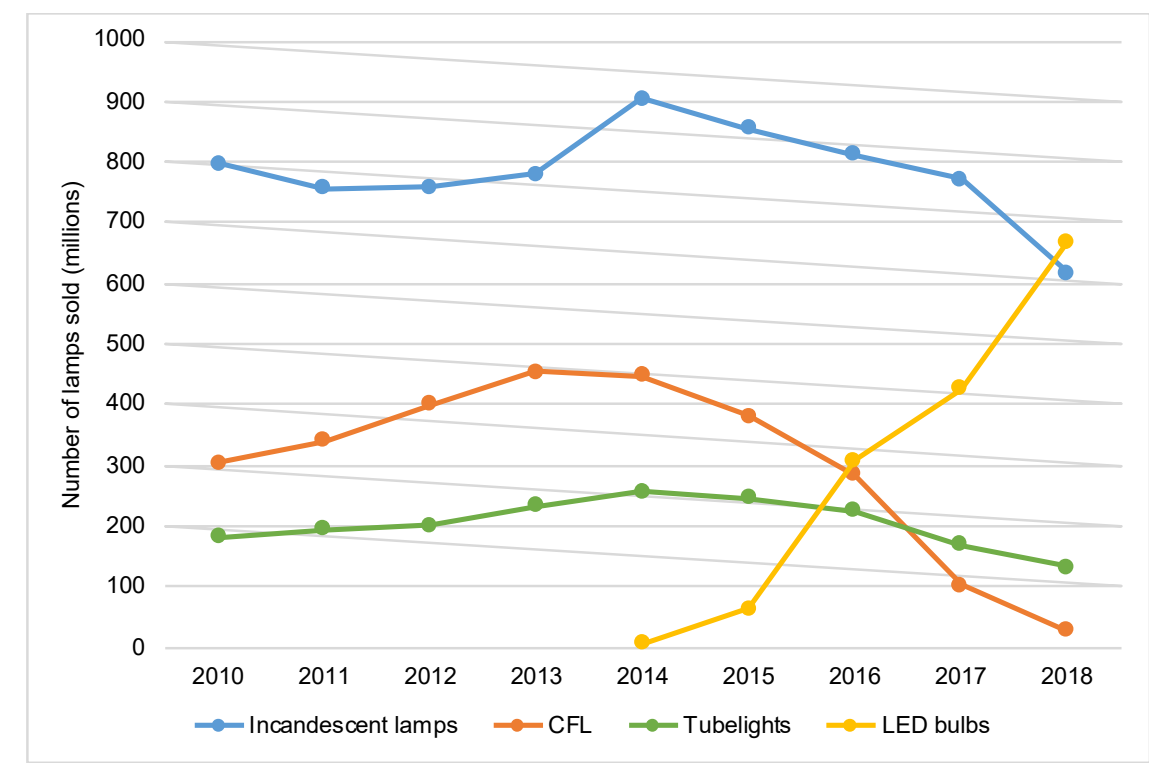

Figure 1: Quantity of lamp sales for different lighting technologies in India between 2010 and 2018. The LED lighting market grew from annual sales of 5 million bulbs to 669 million bulbs. Data source: ELCOMA [32].

Prior to 2014, the domestic LED lighting market and manufacturing ecosystem were small. The only government policy focusing on LED lighting was a government-funded R\&D program, which began in 2007 and involved a network of public-sector research institutes [22].

The unexpected market expansion starting in 2014 was driven by a government-led LED market formation program, motivated by India's fast-increasing domestic energy demand - estimated to be the largest future contributor to the global energy demand growth [33]. The government program, implemented by a joint venture between four public-sector utility companies, aggregated national demand to procure LED bulbs from companies via a competitive bidding process for the lowest price. It was guided by ambitious market expansion targets set forth by the government for residential LED bulbs and LED streetlamps [34]. The residential bulbs were distributed to consumers across the country through a network of venders and kiosks, a relatively new market mechanism, at lower-thanmarket price [34]. Through effective end-to-end execution, the program successfully leveraged the large scale of India's urbanizing domestic market to spur LED growth and drove down the procurement prices of residential LED bulbs from USD 6 in 2014 to USD 0.6 in 2016 [22]. By 2016, India accounted for about $10 \%$ of the global LED bulbs market from a negligible share in 2014 [22].

The successful transition is a result of multiple factors, beyond the market creation policy model. Importantly, it was enabled by lighting companies in India relying heavily on Chinese LED manufacturers to supply large quantities of LED bulbs to start with, and later chips and driver integrated circuits, at low cost [34] [22]. At the same time, growing demand necessitated domestic industrial R\&D for newly designed control electronics so that imported LED bulbs could withstand the large fluctuations in India's electricity supply [35]. The domestic manufacturing ecosystem was also enhanced by the government's LED tenders mandating domestic-content requirements in the procured bulbs [22], [34]. Given rapidly expanding LED bulb market, within five years the established incandescent and compact fluorescent bulb manufacturing facilities, including factories of foreign multinational companies, were reconfigured to assemble LED bulbs, expanding the LED bulb assembly ecosystem to over 400 LED bulb manufacturing units by 2018 [22]. Spillover effects from other industries also played a part in manufacturing expansion: manufacturing capacity for the enclosure of LED bulbs and the heat sink benefitted from the technical know-how in India's autocomponents manufacturing industry [22]. 
India's LED lighting transition thereby involved all seven TIS functions: knowledge development through industrial R\&D and increasing research capabilities in public-sector research institutions and universities; knowledge diffusion through spillovers from manufacturing capabilities for older lighting technologies and auto industry component manufacturing; entrepreneurial experimentation through establishment of a new public-sector company and new private-sector LED assembly units; the government's ambitious LED lighting deployment targets and market formation policy initiative; investments by the new public-sector enterprise and industry; and legitimation of LED lighting as a climate-friendly and emissions-reducing technology through public awareness campaigns. It is also worth noting that the public sector and policy played a leading role throughout (as is seen in in Error: Reference source not found).

However, in spite of the dramatic growth in India's solid-state lighting market, domestic manufacturing capabilities did not grow as fast as the rising market demand. LED chips and driver integrated circuits are not domestically manufactured due to the absence of commercial semiconductor fabrication capabilities. Long-standing domestic R\&D capabilities, too, although growing quickly, were not leveraged to support the government's LED program and instead remain siloed within universities and research institutes [22]. Although planned since the $2007 \mathrm{R} \& \mathrm{D}$ program, technology transfer from research institutes to industry did not succeed [22]. In addition, weak enforcement of technology standards and fierce competition to bid lower prices resulted in declining quality of the procured LED bulbs [22].

India's LED transition took place amid a complexity of different actors, institutions, and their interactions. While rapid market expansion, new business models and new product distribution mechanisms were deployed through policy, it led to the need for quickly ramping up domestic industrial $\mathrm{R} \& \mathrm{D}$ due to challenges from the local electricity infrastructure, and drawing on technological spillovers from another industry - with unintended consequences of increase import dependence and declining bulb quality.

\section{Powering solar photovoltaics in China}

In the last two decades, China has become the leading global manufacturer and largest market for silicon-based PV cells and modules (Error: Reference source not found). 


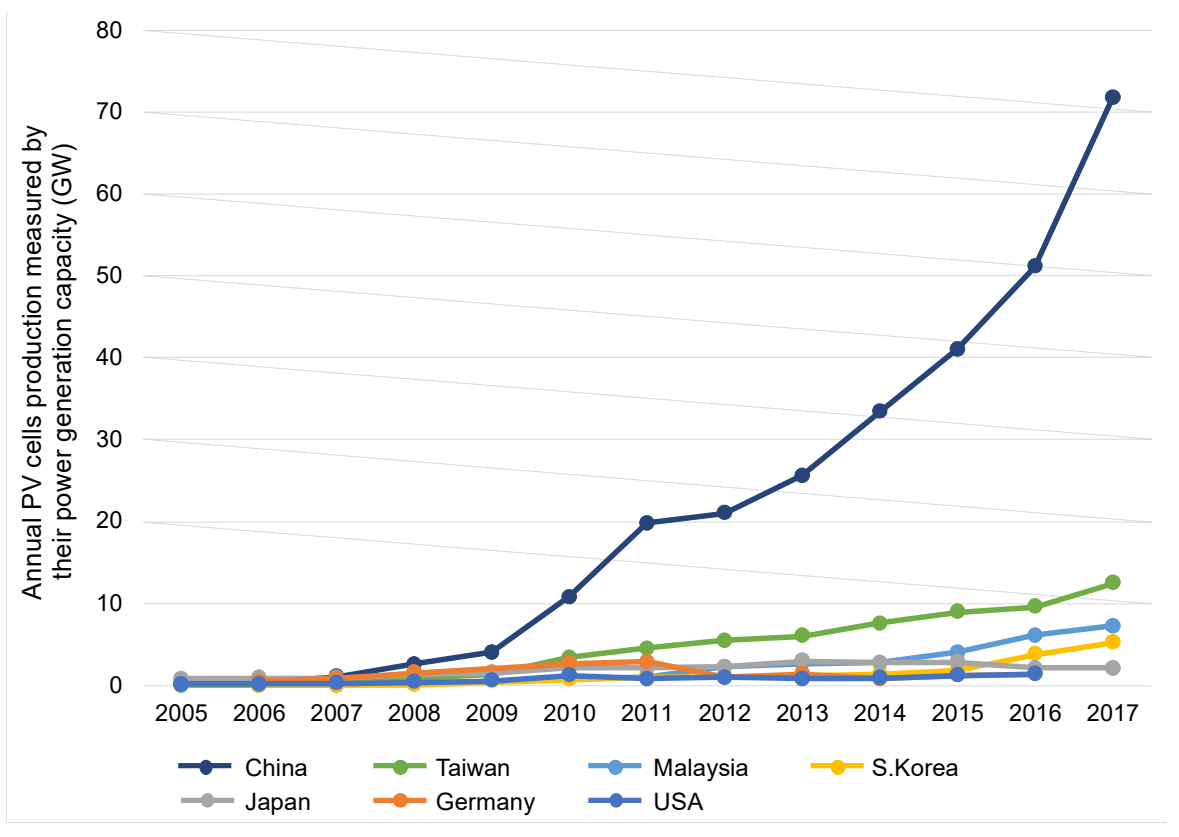

Figure 2: Annual photovoltaic cell production capacity in leading countries between 2005-2017. China's manufacturing capacity increased more than 25 times during 2008-2017, making it the top exporter of photovoltaic cells, accounting for $69 \%$ of the global cell production. Data source: Multiple IEA-PVPS reports [36], [37].

Until the late-1990s, the Chinese PV manufacturing industry and market were small, rife with quality issues, and dominated by a few government-owned manufacturing firms [18]. The technological transition was triggered around 2000 by the rise of private PV manufacturing start-ups, founded by Chinese experts returning with PV research and industry experience in developed countries [38].

The returning experts became important actors in the emergence of China's PV manufacturing ecosystem as start-up founders and top management [18], [38], [39]. Indeed, four of the private PV manufacturing start-ups founded at the time are now the leading PV cells and module manufacturers in the world [38]. Chinese policies at the time were increasingly favourable to high-tech, exportoriented manufacturing industries. However, beyond the inclusion of PV in national R\&D programs [40], [41], PV-specific policies to support industry growth or large-scale market expansion were absent until the mid-2000s [41], [42]. The new start-ups benefitted from (non-PV-specific) incentives for high-tech manufacturing including fiscal incentives, such as tax breaks, access to low-cost electricity and land, subsidized loans, and investments from provincial and municipal-level governments, state-owned enterprises and regional banks [20], [38].

The new PV start-ups focused on exporting to rapidly growing international markets in Germany, other European countries, and later, the US, in the absence of domestic PV demand [18]. These manufacturers competed with foreign PV manufacturers in cell and module manufacturing by lowering costs through economies of scale, by upscaling factories (lax enforcement of environmental laws helped speed up the process), and through industrial R\&D to develop cheaper module components and manufacturing processes [18], [43]. They also leveraged relationships with foreign universities and industry to acquire the technical know-how for state-of-the-art Chinese PV production lines, based on the founders' prior research and industry experience in developed countries [38]. While initially PV production equipment was imported from foreign manufacturers, domestic manufacturers gradually developed good-quality yet cheaper equipment [43]. Domestic equipment manufacturing benefitted from the experience of Chinese machinery manufacturers in the semiconductor industry [18]. However, China still depended on import of polysilicon used to manufacture PV cells [39], [44]. 
By 2008, China was the top PV cells and modules manufacturer and exporter in the world (refer to Error: Reference source not found). The industry began investing heavily to move into other value chain segments, specifically polysilicon production and related equipment manufacturing [45]. As a result of China's demonstrated manufacturing capabilities and competitiveness, foreign investments in PV manufacturing and government investment to support domestic industrial capabilities in polysilicon production also increased [38], [39]. In 2010, state-owned banks provided approximately $\$ 34$ billion in loans to the PV manufacturers, compared to global PV venture capital investment of $\$ 1.7$ billion that year [41].

Subsequently, with an introduction of anti-dumping disputes and tariffs on Chinese PV products, the demand from European and US markets slowed down (EU anti-dumping tariffs ended in 2018 while US tariffs have lowered but continue) [18], [41]. In the wake of slowing foreign demand, Chinese PVspecific large-scale market expansion policies began in 2009 with subsidy grants for capital costs of residential, commercial, and utility-scale PV projects [42]. In 2010, Chinese national, provincial, and municipal governments ramped up demand-pull policies, such as feed-in-tariffs, to accelerate domestic utility-scale PV market expansion [41]. China became the biggest global PV market in 2015 [46].

We can observe two phases in China's PV technology transition, each characterized by different patterns of the TIS functions (refer to Error: Reference source not found). The first, from the late 1990s to mid 2000s, was initiated by private PV start-ups of the Chinese diaspora, despite the absence of PV-specific industrial or market expansion policies. Not all TIS functions were active during this period. The active functions were: knowledge development through industrial R\&D; knowledge diffusion through the diaspora and their international networks and through imports of equipment and spillovers from the semiconductor industry; entrepreneurial activities of private start-ups in PV cell and module manufacturing and equipment manufacturing; financial resource mobilization through manufacturing investments by industry and public-sector enterprises; and technology legitimation by including PV in the list of priority areas for R\&D. However, PV-specific policies for domestic industry and market growth were absent, i.e. TIS functions of policy guidance for direction of market and technology and market formation were inactive. During this phase, the complementarity between market expansion in Germany and domestic start-ups also enabled rapid enhancement of PV manufacturing capabilities.

The second phase from the late 2000s continued the focus on manufacturing accompanied by aggressive domestic market expansion and supporting PV government policies. While broader policies helped facilitate in the first period, PV-specific policies were implemented only since 2009. As a result, the activity of the first phase functions enhanced and additional functions became active: knowledge development through increased university and public-sector research; entrepreneurial experimentation to expand polysilicon production and equipment manufacturing; government targets for growth of the domestic PV market along with PV market expansion policies; domestic investments and FDI in Chinese PV manufacturing; and the overall growing support for PV from central, provincial and municipal governments despite high PV costs.

Overall, in spite of its large market and manufacturing capacity, the transition is also market by weaknesses in functions. Chinese industrial R\&D focused on short-term returns and PV system developers can sacrifice quality to lower costs for the domestic market [18], [43]. Growing R\&D capabilities in Chinese universities and research institutions are also not yet strongly linked to the industry's growth [18]. Industry's short-term view and weak research to market linkages could prove to be a hindrance in maintaining China's leadership especially if the global PV market transitions to the next generation of non-silicon PV technologies [43]. 


\section{Fuelling ethanol from sugarcane in Brazil}

In the last four decades, Brazil has risen as the largest producer, exporter, and market for sugarcane ethanol fuel (Error: Reference source not found). Of the three cases discussed in this Perspective, Brazil's transition began the earliest and unfolded over the longest period.

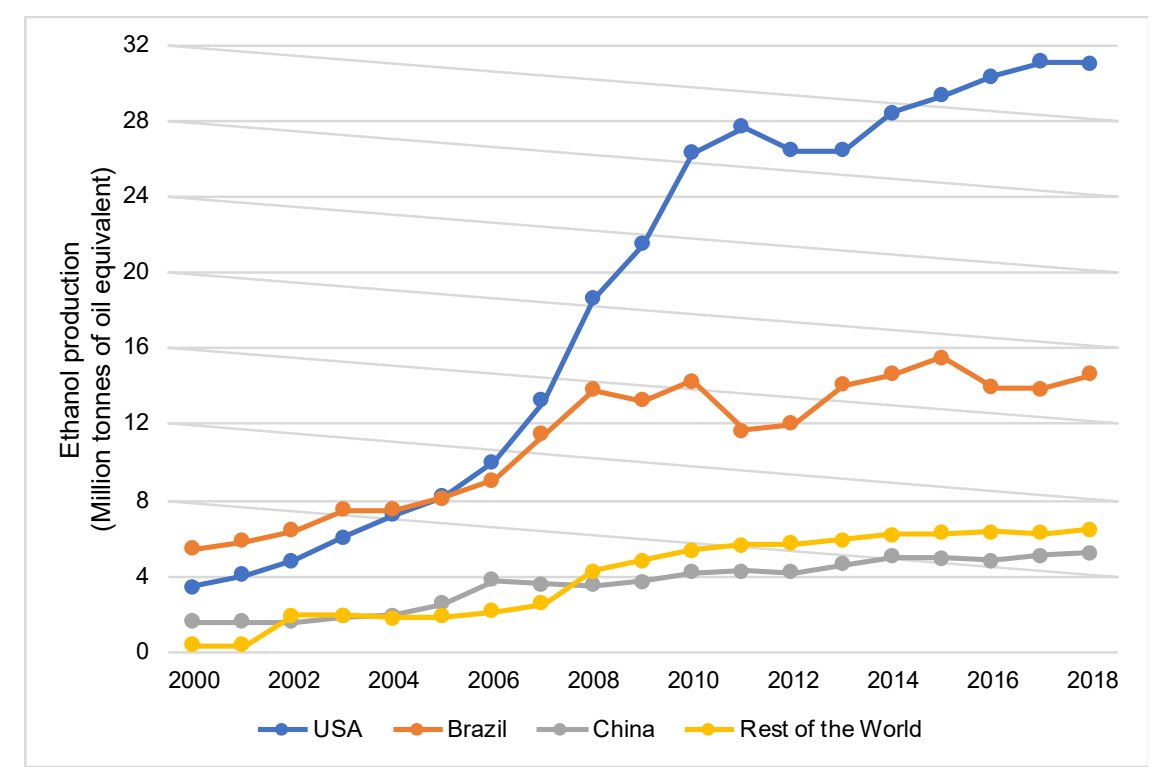

Figure 3: Ethanol production by country between 2000-2018. Note that ethanol produced in the USA is almost entirely sourced from corn, whereas Brazil's is sourced from sugarcane which has lower life-cycle carbon emissions than corn ethanol [47]. Brazil's production tripled, making it the world's top manufacturer of sugarcane ethanol. Source: OECD Statistics (https://stats.oecd.org/).

Brazil's sugarcane ethanol industry exists since the early $20^{\text {th }}$ century, but the market and production of ethanol as an automotive fuel was small until 1970 [48]. Motivated by energy security given the 1970s increase in international oil prices, the military government of Brazil initiated large-scale policy initiatives to subsidize ethanol production and mandate the use of ethanol-gasoline blend as an automotive fuel [48], [49]. Specifically, the government-funded collaborative R\&D between the ethanol industry and public-sector research institutions made ethanol production more cost-efficient (to compete with oil) [49]. Alongside, the auto-industry, including Brazilian subsidiaries of foreign auto-makers, focused R\&D on modifying engines to run on high-ethanol-content fuel [48]. These supportive policies by government and industry motivated new entrants in the ethanol industry to scale production and invest in technological innovation [48], [50].

From the initiation of the ethanol program, the public-sector oil company Petrobras played a leading role in bridging the ethanol production industry with ethanol fuel customers. Petrobras had national monopoly in storage and distribution of oil, with the largest national network of fuelling pumps [51]. It guaranteed purchase of ethanol from ethanol mills, provided ethanol storage and transport services for ethanol producers and fuelling services to ethanol-car owners [48], [51]. (This is similar to India's case where a public-sector enterprise aggregated national demand and took over distribution of LED bulbs through new market mechanisms). Consequently, the share of ethanol-run vehicles in Brazil's new light-vehicle sales increased from $\sim 30 \%$ in 1980 to $>90 \%$ in 1985 [52].

Subsidies for ethanol production continued under the civilian government in the 1980s, but slowly declined in the 1990s due to falling oil prices which stagnated ethanol growth [48], [49].Further, 
consequent financial losses led to opposition from Petrobras for ethanol subsidies and price control [51], [53]. Few ethanol producers survived this downturn (those who had invested in R\&D and economies of scale to increase production efficiencies), and by 2002, hardly any new ethanol-run vehicles were sold in Brazil [48], [49] [52]. However, the technological transition to ethanol was reignited in the early 2000s with the re-emergence of international interest in biofuels as an alternative to gasoline amid emerging climate change concerns. Brazilian subsidiaries of foreign automakers, such as Volkswagen, General Motors, and Fiat, tapped into this opportunity by developing and launching flex-fuel vehicles that can run on either gasoline, ethanol or their mix - a technology in development in US, Europe, and Japan since 1980s [49]. The government also extended subsidies to flex-fuel vehicles [48], [49], and the share of flex-fuel vehicles in new light-vehicle sales increased from negligible in 2003 to $87 \%$ in 2008 and stayed relatively stable since [52]. Ethanol production technologies also improved during this period through growth of cellulose ethanol and cogeneration of electricity and commercial use of by-products from ethanol production [54].

Overall, three periods with distinct patterns in TIS functions can be observed in Brazil's sugarcane ethanol transition, each with its set of complexities. In each period, the changing influence of a variety of actors (e.g. supportive government policies, industry-initiated revival) resulted in the rise, stagnation, and revival of the transition. First, from 1970 to mid-1980s, the transition was initiated by policy initiatives by the military government that stimulated R\&D, industry growth and market expansion. All seven TIS functions were active during this period: knowledge development and diffusion through collaborative $\mathrm{R} \& \mathrm{D}$ between public-sector research institutions and industry; entrepreneurial activity by new entrants in ethanol production; government targets for ethanol production and mandates for its use; financial resource mobilization through government subsidies, price control and industry investments; and legitimation of ethanol through strong government support.

Second is a period of stagnation from late 1980s until 2002, when the military regime was replaced by a civilian government, subsidies and cost competitiveness of ethanol with gasoline declined, and the ethanol production industry restructured to survive. This period is marked by declining performance of all TIS functions, with industrial investments aimed at survival.

The third period of the revival of the technology transition since 2003 was initiated by Brazilian subsidiaries of foreign auto manufacturers through introduction of flex-fuel vehicles. All seven TIS functions were rejuvenated: knowledge development through auto industry R\&D for flex-fuel vehicles and for cellulose ethanol technology; international knowledge diffusion in flex-fuel vehicle technology; entrepreneurial experimentation with cogeneration of electricity and sales of ethanol byproducts; policy guidance and market formation through government targets and subsidies (the latter are also investments); rising industry investments in ethanol production; and legitimation due to strong government support motivated by climate concerns, economic and job growth.

In these four and a half decades, Brazil has developed an entire technological innovation system for sugarcane ethanol, from subsidies and technological advances in production to flex-fuel vehicles developed and sold by subsidiaries of foreign multinationals. Despite political regime changes and economic crises, and diminishing political support during 1990s, not all supportive policies for sugarcane ethanol were rescinded, exemplifying the importance of long-term consistent policy for technology transitions [49].

\section{Learning from low-carbon technology transitions in emerging economies}

What can these three diverse country examples of rapidly deploying clean energy solutions tell us about accelerating low-carbon technology transitions in emerging economies? Drawing from these different innovation approaches in varied regions, we distill what is common in making these rapid transitions successful, in spite of their relatively weak innovation system starting points. 
We draw from the successes and barriers within the seven TIS functions detailed in Table 1 (for conceptualization of barriers in TIS refer to [55]). We focus on commonalities among key actors, institutions, and their patterns of interactions which were either enablers or weaknesses in the transition. We particularly study those characteristics whose role is not yet well understood in the technological transitions literature. Of the three insights below, one relates to a specific actor (publicsector enterprises), another to interactions between institutions and actors (complementarity of domestic policies and global value chains), and the third to interactions between specific actors (innovation linkages between universities and industry).

\section{Role of public-sector enterprises in leveraging economies of scale}

The significance of economies of scale in cost reduction of low-carbon technologies is well evidenced [56], [57]. This is salient for the large market potential in emerging economies, enabling unique opportunities to leverage capital investments and accelerate technologies. Yet understanding the mechanisms and actors that stimulate economies of scale in developing countries remains limited [5].

As seen for India, China and Brazil, the size of the domestic market and the role of public-sector enterprises (PSEs) (i.e. business enterprises with significant equity owned by one or multiple governments) can be crucial in leveraging economies of scale. Public-sector enterprises operate at the interface of policy and industry and can be instrumental in implementing specific policy initiatives while also engaging in financial resource mobilization and business activities that other government agencies cannot participate in [58]. While the role of PSEs in technological transition is recognized in the literature, here we highlight that PSEs are particularly well-positioned to leverage economies of scale in large emerging economies.

For instance, in India, four public-sector electric utilities established a joint-venture company which aggregated national demand to scale-up the LED market and reduce prices using competitive bidding, public awareness (marketing) campaigns, and new distribution channels [22]. In China, public-sector enterprises provided venture capital investments and loans that enabled rapid expansion of privatesector PV manufacturing startups [38]. Even after the startups raised additional capital from foreign investors, public-sector enterprises remain key financiers of Chinese PV manufacturers [41]. In Brazil, Petrobras, the leading public-sector oil company (and the only one initially mandated by the government) played the foremost role nationally in bridging the ethanol production ecosystem to consumers' fuel point-of-purchase by purchasing ethanol from mills, providing ethanol storage and transport services, and distributing fuel through its largest fuel pumps network in the country [48], [51].

Thus, the mix of policy and business instruments at the disposal of PSEs in emerging economies, where financial resources can be restricted, scales of operation are large, and where policy is expected to play a large role in addressing challenges, place them in an important role to speed-up climate change solutions.

It should be emphasized that the nature and role of public-sector enterprises and the opportunities they present may vary dramatically depending on inter alia the government structure of the country and its industrial policies. With the backdrop of a communist government structure, many of the largest Chinese manufacturers in most high-tech industries are PSEs fully owned by the government or joint ventures with Chinese or foreign private enterprises. In contrast in India's democratic governance structure (and legacy of socialist policies), public-sector enterprises operate in selected industries, including industries such as defense-related manufacturing (fully government-owned), metallics and oil and natural gas production (public-private partnership with majority government stake), and services industries such as telecommunication, rail transport, and energy services (fully government owned or public-private partnerships). ${ }^{i i}$ In Brazil, too, public-sector enterprises operate only in a few industries, such as oil and gas, telecommunication, and agricultural production. After the regime 
change away from a military dictatorship in the 1980s, the Brazilian government fully privatized PSEs in many industries and ended national monopolies of PSEs in other industries.

In much contrast, in the US, PSEs are altogether not present in manufacturing industries. Publicsector development banks, power-generation companies, and electric utilities, on the other hand, are common forms of PSEs around the world (including the US). PSEs' involvement in business activities also faces varying challenges. For example, large-scale subsidized loans by Chinese publicsector banks to PV manufacturers have been a central issue in the US and Europe's anti-dumping disputes with China over PV products imports.

\section{Domestic policies to complement positioning in global value chains and reduce costs}

Policy making for technology transitions ideally involves both supply-push policies to support manufacturing and demand-pull policies for market growth [59]. Neither are necessarily rapidly implementable: it can take a long time to build and scale manufacturing capabilities, and analogously large-scale investments for market expansion can take time and resources [59]. This is even more difficult in countries where finances are restricted. As is increasingly recognized in the clean energy transitions literature on developing countries (mainly in the context of technology transfer and catchup), transnational linkages can fill in to compensate for such domestic weaknesses [8], [24]. However, technology transfer without locally embedded supportive mechanisms cannot sustain a full-scale transition [5].

We argue that transnational linkages can be further leveraged through complementary domestic policy approaches. Specifically, a country's position in global value chains allows them to prioritize supplypush or demand-pull policies, based on the country's local innovation systems and characteristics of the specific technology, to enable accelerated transitions. Leveraging this complementarity between country policy approaches and global value chains reinforces an emphasis on systems thinking in policy design and that domestic technology policy choices succeed only if they take into account the entire innovation system, which may span multiple countries and connect intricately with other technologies.

India, China and Brazil all drew on the strengths of their position in global value chains and innovation networks to prioritize their domestic choices. India could accelerate its LED market creation because its demand aggregation policies complemented access to China's large-scale lowcost LED lamp and component manufacturing [22] which lighting companies including subsidiaries of multinational companies continue to use. Similarly, China's domestic support of export-oriented high-tech manufacturing complemented the growing PV demand in international markets and the cross-border flows of knowledge [18]. In Brazil, both supply-push (production subsidies) and demand-pull (price control and car-owner subsidies) policies were implemented for the ethanol industry during the first and the third phase of the transition, with the global auto industry leading R\&D and manufacturing of ethanol-run and flex-fuel cars [49]. These cases also point to the complex nature of North-South and South-South flows of goods, services, human capital, knowledge, and technologies, as opposed to a one-way transfer from the North to the South. Such transnational linkages can support accelerated low-carbon technology transitions in emerging economies if policies of the latter complement their positioning in global value chains.

\section{Importance of domestic $R \& D$ and university-industry linkages}

While the role of public- and private-sector R\&D activities is central to energy innovation [28], $R \& D$ activities in developing countries often have a slower pace in realizing new market-suitable technologies. Clean-energy technology transitions in these contexts can begin after R\&D, demonstration, and commercialization of a new technology has already taken place in developed countries. In spite of this drawback, and notwithstanding the opportunities from global value chains and prioritizing domestic policy choices, domestic R\&D activities to advance indigenous innovation 
capabilities are essential for rapid low-carbon technology transitions in emerging economies [26], [60], [61]. Recognizing the role of domestic R\&D to ensure long-term economic growth with energy and climate security, developing economies have been ramping up their R\&D investments in recent decades [30]. However, the contribution of research capabilities to the economy is predicated on whether the innovation system can translate research outputs into innovation. Although the importance of domestic R\&D and university-industry linkages is well understood in the broader field of innovation studies, we highlight it here for two reasons. One, specific instruments to strengthen linkages to enable translation of research outputs into innovation have not been studied in detail in developing country contexts. And two, given the advancements in clean energy research and industrial capabilities in emerging economies so far, university-industry linkages are especially critical at this time for policy and research to enable future clean energy technology innovation pathways in these countries. Because overall innovation systems in emerging economies are at less mature stages as compared to those in developed countries, such linkages often don't form organically and require deliberate effort.

It is important that R\&D to innovation should not be interpreted as a linear process, for it involves non-linear interactions and feedbacks among early $R \& D$, design and development of products, market demonstration, commercialization and formation, and technology diffusion [62]. Studies focusing on innovation in developing countries have also observed new forms of innovation taking place outside the conventional R\&D laboratory settings - e.g. grassroots innovations by community inventors [24]. Furthermore, due to interdependence among various technologies, future energy innovation also requires interdisciplinary research on multi-purpose or platform technologies [63] without artificial barriers between basic and applied research [64]. Here, we are referring to the complex non-linear process of translating knowledge into innovation and systemic linkages among multiple actors contributing to the generation, diffusion, and utilization of technologies.

Drawing from the countries examined, domestic industrial R\&D was necessary for the success of technological transitions. In India, some industrial R\&D was needed to design LED lamp electronics for imported bulbs to withstand the country's electricity fluctuations. Industrial R\&D by Chinese PV manufacturers was among the enablers of cost reductions of module components and equipment to contest with incumbent competitors abroad. However, in both countries, industry focused on the short term with R\&D efforts limited to adaptation of products created for, or by, developed countries. Further, despite rapidly advancing capabilities of their research ecosystems in respective technologies, these capabilities played a very limited role in translation to market innovation and instead worked with artificial divides between basic and applied research [64] [22], [38], [43], [65]. These weak linkages limit the ability of emerging economy industrial bases to take advantage of future technological breakthroughs (e.g. concerns about whether China will maintain its position as the top PV manufacturer if the global market shifts to non-silicon PV technologies [43]). While manufacturing capabilities can still grow in the absence of such linkages, innovating at the cleanenergy technological frontier requires bridges between the research ecosystem and industry. Brazil's ethanol case exemplifies the importance of such linkages, where government-funded collaborative R\&D between public-sector research institutes and the ethanol production industry advanced technology to be cost competitive with gasoline and the capabilities developed helped ethanol producers survive even when subsidies declined [49]. Moving forward, this missing link between industrial R\&D and the research ecosystem and market needs to be bolstered, especially in emerging economies to scale technologies beyond niches to full market scale.

\section{Looking ahead: scholarly and policy perspectives}

Taking an integrated view of the accelerated clean energy technology transitions in India, China, and Brazil reveals key research and policy insights about the drivers of successes and shortcomings. They point to the role of public-sector enterprises in leveraging economies of scale; reinforcing 
complementarities between global value chains and related domestic technology policy choices; and strengthening domestic academia-industry $\mathrm{R} \& \mathrm{D}$ linkages as an integral part of the energy policy mix. These insights are not country- or technology-specific but have broad applicability and warrant deeper exploration. In all cases, a supportive policy environment is crucial to carefully identify and strengthen weak elements of the innovation system, as in emerging economies, technology capabilities often exist in a few select industries and in some (not all) parts of the technology supply chain [7], [24].

These insights may apply to different extents to larger emerging economies versus smaller developing countries. For example, because smaller developing countries have smaller markets as compared to the countries discussed, they have smaller domestic market-wide economies of scale to leverage. As the scales of their industrial bases and national innovation systems are also smaller, the complementarity between domestic policies and global value chains becomes even more critical because often only a small part of the global value chain of a technology can be developed domestically. For the same reason, smaller developing countries may also have to focus on building innovation capabilities in fewer industries and technologies, compared to the larger economies.

The approach of this perspective and its insights point to directions for future research.

The role of public-sector enterprises, specifically, in economies of scale calls for further research on innovative policy instruments for large-scale financial resource mobilization (beyond conventional subsidies or tax exemptions) for rapid transitions [58]. This aligns with a recent cross-country comparative analysis of technological transitions which argued for the importance of policy initiatives that take into account multiple dimensions of technological transitions [66]. To understand complementarities between global value chains and domestic policy approaches requires research to conceptualize these relationships and with deeper analysis to derive policy recommendations [67]. Similarly, linkages between the research ecosystem and industry need to be conceptualized so as to enable universities and research institutes to leverage less formalized local knowledge networks that can help scale up grassroots or frugal innovations - forms particular to developing contexts and important for inclusive transitions [24]. These areas are also interrelated. For example, optimal business strategies of public-sector enterprises in low-carbon technology transitions will depend on their positioning within global value chains and their R\&D capabilities including the ability to access and commercialize research outputs. This reemphasizes the need for systems thinking in policy design that takes into account opportunities and challenges in the global innovation system. R\&D funding to universities, too, will lead to innovations if support for university-industry linkages is embedded in R\&D funding models, such as long-term academia-industry collaborations and public-private partnerships. Moreover, industry will succeed at commercializing outputs of R\&D only if industryrelated policies support existing enterprises as well as new entrepreneurs to appropriately position themselves in evolving global value chains.

From a scholarly point of view, this perspective points to the usefulness of comparative technological transition studies as a tool for cross-country and cross-technology analyses to extract insights that are broadly applicable across geographies and technologies. Such multi-technology studies would be especially insightful given the need for more encompassing systems perspective in future policies and forward-looking studies, in order to explicitly capture the interdependence between multiple technologies and sectors [63]. Brazil's ethanol transition, for example, provides a glimpse into the dependencies between agriculture-based fuel and automobile technologies. Looking forward, due to the intermittent nature of solar and wind energy, the phase-out of fossil fuel electricity will depend on the diffusion of other technologies such as utility-scale battery storage or nuclear energy. Another forward-looking example is electrification of transportation, which is imminent across growing economies. Climate benefits from vehicle electrification depend on whether the electricity is 
generated from fossil fuels or renewable energy sources [68]. This is another quintessential case of the need for a multi-technology systems perspective.

The unexpected clean-energy transitions in India, China, and Brazil demonstrate that emerging economies can lead globally in low-carbon technology supply and demand. However, accelerating such transitions requires a holistic approach, with a shift from isolated policy approaches to a portfolio of coordinated innovation policies where demand, R\&D, and manufacturing are all strategically developed - especially if they are initiated from a place of technological and economic lag. Further research through retrospective and forward-looking studies of accelerated clean-energy transitions across countries and technologies are crucial to informing such accelerations which will be demanded across emerging economies. Success or failure in this endeavour will have long-term global energy and carbon consequences. 
Table 1 Technological innovation systems functions approach applied as an organizing framework to study successes and barriers in India's LED transition, China's PV transition, and Brazil's sugarcane ethanol transition. (PSE: Public-sector enterprises).

\begin{tabular}{|c|c|c|c|c|c|c|}
\hline & India & China & & Brazil & & \\
\hline $\begin{array}{l}\text { Background and } \\
\text { TIS functions }\end{array}$ & $\begin{array}{l}\text { India (2014 } \\
\text { onward) }\end{array}$ & $\begin{array}{l}\text { China (Phase I: } \\
\text { 1990-mid-2000s) }\end{array}$ & $\begin{array}{l}\text { China (Phase II: } \\
\text { mid-2000s onward) }\end{array}$ & $\begin{array}{l}\text { Brazil (Phase I: } \\
\text { 1970s-mid 1980s) }\end{array}$ & $\begin{array}{l}\text { Brazil (Phase II: } \\
\text { 1980s-2002) }\end{array}$ & $\begin{array}{l}\text { Brazil (Phase III: } \\
2003 \text { onward) }\end{array}$ \\
\hline Background & $\begin{array}{l}\cdot \text { Until 2013, LEDs } \\
\text { had a small market } \\
(<5 \text { million } \\
\text { bulbs/year) with } \\
\text { negligible domestic } \\
\text { manufacturing. } \\
\text { - Multi-institute } \\
\text { R\&D program } \\
\text { initiated in 2007. } \\
\text { [22], [32], [34]. }\end{array}$ & $\begin{array}{l}\text { - Until mid-1990s, } \\
\text { small market and } \\
\text { industry, only PSE } \\
\text { manufacturers, and } \\
\text { many quality issues } \\
{[18],[45] .}\end{array}$ & & $\begin{array}{l}\cdot \text { Until 1970s } \\
\text { Small ethanol } \\
\text { production, small } \\
\text { market. Oil imports } \\
\text { cost half of Brazil } \\
\text { foreign exchange } \\
\text { from exports [48], } \\
\text { [54]. }\end{array}$ & $\begin{array}{l}\text { - This stage is one } \\
\text { of TIS decline, } \\
\text { owing to the } \\
\text { barriers in functions } \\
\text { discussed below } \\
\text { (except for F3, F6) }\end{array}$ & \\
\hline $\begin{array}{l}\text { Technology } \\
\text { transition } \\
\text { initiation }\end{array}$ & $\begin{array}{l}\text { - Initiated by } \\
\text { government } \\
\text { initiative; } \\
\text { implemented } \\
\text { through a PSE [22]. }\end{array}$ & $\begin{array}{l}\text { - Initiated by private } \\
\text { startups with } \\
\text { returning Chinese } \\
\text { from the diaspora } \\
{[38],[44],[69] .}\end{array}$ & & $\begin{array}{l}\text { - Initiated by the } \\
\text { government leading } \\
\text { to an increase in } \\
\text { sugarcane } \\
\text { plantation, ethanol } \\
\text { production, and } \\
\text { share of ethanol-run } \\
\text { cars in Brazil's auto } \\
\text { market [48], [49], } \\
\text { [51]. }\end{array}$ & $\begin{array}{l}\text { - This phase is } \\
\text { arrived at from a } \\
\text { stagnation of } \\
\text { ethanol production; } \\
\text { opposition from } \\
\text { Petrobras; declining } \\
\text { govt. subsidies; } \\
\text { ending of ethanol } \\
\text { policy initiative of } \\
\text { 1970s in 1991; and } \\
\text { changes in fiscal } \\
\text { incentives to car } \\
\text { owners benefitting } \\
\text { gasoline-blended } \\
\text { cars more than } \\
\text { ethanol-run cars }\end{array}$ & $\begin{array}{l}\text { - Initiated by auto- } \\
\text { industry through } \\
\text { introduction of flex- } \\
\text { fuel vehicles (FFVs) } \\
{[48],[49] .} \\
\text { - Increase in } \\
\text { sugarcane } \\
\text { production, ethanol } \\
\text { production, FFV } \\
\text { demand. }\end{array}$ \\
\hline
\end{tabular}




\begin{tabular}{|c|c|c|c|c|c|c|}
\hline & & & & & $\begin{array}{l}{[48],[51],[53],} \\
{[70]-[72] .}\end{array}$ & \\
\hline $\begin{array}{l}\text { F1: Knowledge } \\
\text { development }\end{array}$ & $\begin{array}{l}\text { - Rising research } \\
\text { capabilities in } \\
\text { universities and } \\
\text { public-sector } \\
\text { research institutes; } \\
\text { industrial R\&D for } \\
\text { control electronics } \\
\text { to withstand } \\
\text { electricity } \\
\text { fluctuations; and } \\
\text { more recent } \\
\text { beginning of } \\
\text { industrial R\&D for } \\
\text { advanced LED } \\
\text { lighting systems } \\
\text { [22]. }\end{array}$ & $\begin{array}{l}\text { - Industrial R\&D by } \\
\text { private startups to } \\
\text { develop local know- } \\
\text { how, lower costs of } \\
\text { processes to } \\
\text { compete globally } \\
\text { [18], [39], [43]. } \\
\text { - Inclusion of PV in } \\
\text { some priority R\&D } \\
\text { technologies [40]- } \\
\text { [42]. }\end{array}$ & $\begin{array}{l}\text { - R\&D in industry, } \\
\text { universities and } \\
\text { public-sector } \\
\text { research } \\
\text { institutions. } \\
\text { - Public-sector } \\
\text { research focus on } \\
\text { polysilicon } \\
\text { production } \\
\text { technology. } \\
\text { - Industrial R\&D to } \\
\text { lower costs of cell } \\
\text { and module } \\
\text { manufacturing and } \\
\text { equipment. } \\
\text { [18], [39], [40], } \\
\text { [45], [73] }\end{array}$ & $\begin{array}{l}\text { - National lab } \\
\text { (CTA) R\&D } \\
\text { support to industry } \\
\text { to test ethanol-blend } \\
\text { and pure-ethanol } \\
\text { engines. } \\
\text { - Industry coalition } \\
\text { Copersucar leading } \\
\text { efforts to develop } \\
\text { improved sugarcane } \\
\text { varieties. } \\
\text { - Govt. R\&D } \\
\text { funding for } \\
\text { collaborative R\&D. } \\
\text { - Auto-sector R\&D } \\
\text { to develop ethanol- } \\
\text { run engines. } \\
\text { [49], [50], [71], [74] }\end{array}$ & $\begin{array}{l}\text { Declined (refer to } \\
\text { Barriers below) }\end{array}$ & $\begin{array}{l}\text { - Auto-sector R\&D } \\
\text { to produce FFV. } \\
\text { - Cellulose ethanol } \\
\text { technology to } \\
\text { reduce costs. } \\
{[72]}\end{array}$ \\
\hline $\begin{array}{l}\text { F2: Knowledge } \\
\text { diffusion }\end{array}$ & $\begin{array}{l}\text { - Spillovers from } \\
\text { old lighting } \\
\text { technology } \\
\text { manufacturing } \\
\text { factories and the } \\
\text { auto industry (for } \\
\text { mechanical parts of } \\
\text { LED bulb) [22]. }\end{array}$ & $\begin{array}{l}\text { - Knowledge and } \\
\text { technology transfer } \\
\text { to China by foreign } \\
\text { equipment } \\
\text { purchase, } \\
\text { international } \\
\text { networks of those } \\
\text { returning from the } \\
\text { diaspora [18], [38], } \\
\text { [39]. }\end{array}$ & $\begin{array}{l}\text { - Relations with } \\
\text { global universities } \\
\text { through networks } \\
\text { continued (refer to } \\
\text { previous phase) } \\
\text { [38], [39]. }\end{array}$ & $\begin{array}{l}\text { - Through } \\
\text { Copersucar, govt.- } \\
\text { funded collaborative } \\
\text { R\&D and CTA } \\
\text { partnership with } \\
\text { industry for engine } \\
\text { testing (refer to F1 } \\
\text { above). }\end{array}$ & $\begin{array}{l}\text { Declined (refer to } \\
\text { Barriers below) }\end{array}$ & $\begin{array}{l}\text { - Tech transfer from } \\
\text { FFV R\&D since } \\
\text { 1980s in US, } \\
\text { Europe, and Japan } \\
\text { through foreign } \\
\text { automakers [49], } \\
\text { [72]. }\end{array}$ \\
\hline
\end{tabular}




\begin{tabular}{|c|c|c|c|c|c|c|}
\hline $\begin{array}{l}\text { F3: } \\
\text { Entrepreneurial } \\
\text { experimentation }\end{array}$ & $\begin{array}{l}\cdot \text { - New PSE } \\
\text { established for } \\
\text { market creation. } \\
\text { - Increase in LED } \\
\text { manufacturing } \\
\text { units; factories of } \\
\text { incandescent bulbs } \\
\text { and CFLs converted } \\
\text { to assemble LEDs. } \\
\text { [22], [34] }\end{array}$ & $\begin{array}{l}\cdot \text { Private startups by } \\
\text { those returning from } \\
\text { the diaspora [18], } \\
\text { [38], [39] in } \\
\text { downstream cell } \\
\text { and module } \\
\text { manufacturing (low } \\
\text { entry barrier) [39]. } \\
\text { - Factory scaling to } \\
\text { lower costs [18], } \\
\text { [38], [39]. } \\
\text { - Start of the } \\
\text { manufacturing of } \\
\text { equipment for cell } \\
\text { and module } \\
\text { production [18], } \\
\text { [39], [43]. }\end{array}$ & $\begin{array}{l}\text { - Moving to new } \\
\text { value chain } \\
\text { segments, namely } \\
\text { polysilicon } \\
\text { production and } \\
\text { manufacturing } \\
\text { equipment, } \\
\text { aggressive in } \\
\text { leveraging } \\
\text { economies of scale } \\
{[18],[45],[75] .}\end{array}$ & $\begin{array}{l}- \text { New ethanol } \\
\text { producers in Sao } \\
\text { Paulo [48], [50]. }\end{array}$ & $\begin{array}{l}\text { - Stagnation of } \\
\text { technological } \\
\text { improvement and } \\
\text { production increase } \\
\text { [53]. } \\
\text { - Industrial } \\
\text { consolidation to } \\
\text { lower costs [49]. }\end{array}$ & $\begin{array}{l}\text { - Cogeneration of } \\
\text { electricity and } \\
\text { commercial use of } \\
\text { byproducts (i.e. } \\
\text { adding new value } \\
\text { chain segments) } \\
\text { [54]. }\end{array}$ \\
\hline $\begin{array}{l}\text { F4: Policy } \\
\text { guidance for } \\
\text { direction of } \\
\text { market } \\
\text { expansion and } \\
\text { technology } \\
\text { improvement } \\
\text { ('Guidance for } \\
\text { search' in [10]) }\end{array}$ & $\begin{array}{l}\text { - Govt. policies with } \\
\text { targets for } \\
\text { residential LED } \\
\text { bulbs and LED } \\
\text { streetlamp market } \\
\text { expansion [34]. }\end{array}$ & $\begin{array}{l}\text { Absent (refer to } \\
\text { Barriers below) }\end{array}$ & $\begin{array}{l}\cdot \text { New PV-specific } \\
\text { ambitious } \\
\text { deployment targets, } \\
\text { achieved ahead of } \\
\text { the timeline, leading } \\
\text { to updating the } \\
\text { targets - from } \\
1.8 \mathrm{GW} \text { target for } \\
2020 \text {, to } 20 \mathrm{GW} \\
\text { target, to }>100 \mathrm{GW} \\
\text { deployment by } 2019 \\
\text { [41], [45], [69], } \\
\text { [75]. }\end{array}$ & $\begin{array}{l}- \text { Mandated use of } \\
25 \% \text { ethanol blend } \\
\text { in gasoline cars. } \\
\text { - Encouragement to } \\
\text { automakers to } \\
\text { produce } 100 \% \\
\text { ethanol-run cars } \\
\text { [48], [49], [54]. } \\
\text { - Govt-set ethanol } \\
\text { production targets } \\
\text { [53]. }\end{array}$ & $\begin{array}{l}\text { - Uncertainty in } \\
\text { political support } \\
\text { (refer to Barriers } \\
\text { below) }\end{array}$ & $\begin{array}{l}- \text { Government } \\
\text { targets for ethanol } \\
\text { cost reduction [54]. }\end{array}$ \\
\hline $\begin{array}{l}\text { F5: Market } \\
\text { formation }\end{array}$ & $\begin{array}{l}\text { - Govt. initiative } \\
\text { implemented by a } \\
\text { PSE to aggregate } \\
\text { national demand } \\
\text { through competitive }\end{array}$ & $\begin{array}{l}\text { Absent (refer to } \\
\text { Barriers below) }\end{array}$ & $\begin{array}{l}\text { - Market expansion } \\
\text { accelerated with the } \\
\text { Golden Sun } \\
\text { Program and Solar } \\
\text { PV building }\end{array}$ & Same as F4 & $\begin{array}{l}\text { Demand declined } \\
\text { (refer to Barriers } \\
\text { below) }\end{array}$ & $\begin{array}{l}\text { - Revival of } \\
\text { subsidies for FFV } \\
\text { car owners [48], } \\
\text { [49]. } \\
\text { - Share of FFVs in }\end{array}$ \\
\hline
\end{tabular}




\begin{tabular}{|c|c|c|c|c|c|c|}
\hline & bidding [22], [34]. & & $\begin{array}{l}\text { program, followed } \\
\text { by FiT since 2011 } \\
\text { [40], [42], [45], } \\
\text { [69]. } \\
\text { - Various } \\
\text { applications such as } \\
\text { solar streetlamps, } \\
\text { solar water pumps, } \\
\text { decorative lights by } \\
\text { central, provincial, } \\
\text { and city govts [44], } \\
\text { [75]. }\end{array}$ & & & $\begin{array}{l}\text { new car sales } \\
\text { increased from } \\
\text { negligible in } 2003 \\
\text { to } 87 \% \text { in } 2008 \text { and } \\
\text { is relatively stable } \\
\text { [52]. }\end{array}$ \\
\hline $\begin{array}{l}\text { F6: Resource } \\
\text { mobilization }\end{array}$ & $\begin{array}{l}\text { - Govt. investments } \\
\text { through PSE for } \\
\text { procurement for the } \\
\text { national market, and } \\
\text { industry } \\
\text { investments to } \\
\text { increase LED bulb } \\
\text { assembly [22], [34]. }\end{array}$ & $\begin{array}{l}\cdot \text { Investments from } \\
\text { industry, PSEs [20], } \\
\text { [38]. } \\
\text { • Human resource } \\
\text { investments through } \\
\text { public education-- } \\
\text { not PV-specific } \\
\text { [38], [39]. }\end{array}$ & $\begin{array}{l}\text { - Increase in FDI in } \\
\text { PV industry [39]. } \\
\text { - PV manufacturers } \\
\text { were listed on } \\
\text { foreign stock } \\
\text { markets [38]. } \\
\text { - Subsidized loans } \\
\text { from public-sector } \\
\text { banks [41]. } \\
\text { - Subsidies through } \\
\text { Golden Sun, Solar } \\
\text { PV building } \\
\text { program, large-scale } \\
\text { demonstration } \\
\text { projects, FiT [40], } \\
\text { [42], [45], [69]. }\end{array}$ & $\begin{array}{l}\text { - Subsidies for } \\
\text { sugarcane and } \\
\text { ethanol production } \\
\text { and low-interest } \\
\text { loans (accounted for } \\
\text { about } 30 \% \\
\text { investment in } \\
\text { ethanol production } \\
\text { capacity by late } \\
\text { 1990s [50], [71]). } \\
\text { - Price control of } \\
\text { ethanol and gasoline } \\
\text { with ethanol prices } \\
\text { 30-40\% below } \\
\text { gasoline prices and } \\
\text { guaranteed } \\
\text { purchase, storage, } \\
\text { transport, } \\
\text { distribution by } \\
\text { Petrobras [50], [51], } \\
\text { [54], [71]. }\end{array}$ & $\begin{array}{l}\text { - Industrial } \\
\text { investments to } \\
\text { acquire smaller } \\
\text { ethanol producers to } \\
\text { avail of economies } \\
\text { of scale to survive } \\
\text { declining subsidies } \\
\text { [49]. }\end{array}$ & $\begin{array}{l}\text { - Fiscal subsidies } \\
\text { (refer to F5 above). } \\
\text { - Industry } \\
\text { investments for } \\
\text { ethanol production } \\
\text { expansion and } \\
\text { production } \\
\text { efficiency } \\
\text { improvement [76]. }\end{array}$ \\
\hline
\end{tabular}




\begin{tabular}{|c|c|c|c|c|c|c|}
\hline $\begin{array}{l}\text { F7: Legitimation } \\
\text { (increasing } \\
\text { legitimacy of the } \\
\text { new technology) }\end{array}$ & $\begin{array}{l}\text { - LED lighting as a } \\
\text { solution to save } \\
\text { energy and mitigate } \\
\text { climate change-- } \\
\text { public awareness } \\
\text { campaign by govt. } \\
\text { including real-time } \\
\text { LED sales } \\
\text { dashboard [22], } \\
\text { [77]. }\end{array}$ & $\begin{array}{l}\text { - Inclusion of PV in } \\
\text { priority R\&D } \\
\text { technologies [40], } \\
{[41] .}\end{array}$ & $\begin{array}{l}\text { - Growing support } \\
\text { of central, } \\
\text { provincial, and city } \\
\text { governments despite } \\
\text { high PV costs [44]. } \\
\text { - Industry patenting } \\
\text { aggressively for } \\
\text { legitimation [39]. }\end{array}$ & $\begin{array}{l}\text { - Strong central } \\
\text { govt. support with } \\
\text { rationale for } \\
\text { reducing oil imports } \\
\text { despite initial } \\
\text { resistance by auto- } \\
\text { and sugar industry } \\
\text { along with } \\
\text { environmental and } \\
\text { land-use concerns } \\
\text { (saved } \$ 70 \text { billion } \\
\text { that otherwise } \\
\text { would have cost for } \\
\text { oil imports by late } \\
\text { 1990s [48], [53], } \\
\text { [70]. }\end{array}$ & $\begin{array}{l}\text { Absent (refer to } \\
\text { Barriers below) }\end{array}$ & $\begin{array}{l}\text { - Government } \\
\text { support for climate } \\
\text { change mitigation, } \\
\text { economic growth, } \\
\text { and job creation } \\
{[50] .}\end{array}$ \\
\hline Barriers & $\begin{array}{l}\text { - Manufacturing did } \\
\text { not grow as fast as } \\
\text { the market [22], } \\
\text { [34]. } \\
\text { - Manufacturing } \\
\text { ecosystem found it } \\
\text { difficult to move } \\
\text { into LED chip and } \\
\text { integrated circuit } \\
\text { manufacturing } \\
\text { segments due to } \\
\text { absence of } \\
\text { commercial } \\
\text { semiconductor } \\
\text { fabrication } \\
\text { capabilities [22], } \\
\text { [78]. } \\
\text { - LED chips and } \\
\text { integrated circuits in }\end{array}$ & $\begin{array}{l}\text { - No domestic } \\
\text { market formation } \\
\text { beyond few } \\
\text { government-funded } \\
\text { PV demonstration } \\
\text { projects [18], [41], } \\
\text { [79]-10 MW } \\
\text { average annual PV } \\
\text { installations } \\
\text { between 1998- } \\
2007 \text {, compared to } 2 \\
\text { GW annual } \\
\text { manufacturing } \\
\text { capacity in } 2008 \\
\text { [44]. First } \\
\text { renewable energy } \\
\text { policy enacted } \\
\text { towards the end of } \\
\text { this period with }\end{array}$ & $\begin{array}{l}\text { - Weak linkages } \\
\text { between industry } \\
\text { and universities } \\
\text { (except for } \\
\text { polysilicon, as } \\
\text { reflected in patents } \\
\text { and increased } \\
\text { polysilicon } \\
\text { production [39], } \\
\text { [40]). } \\
\text { - Weak } \\
\text { implementation of } \\
\text { central policies by } \\
\text { some of the local } \\
\text { governments in } \\
\text { states with large } \\
\text { fossil-fuel resources } \\
\text { [44]. } \\
\text { - Anti-dumping }\end{array}$ & $\begin{array}{l}\text { - Govt. faced } \\
\text { resistance to ethanol } \\
\text { as it reduced supply } \\
\text { of sugarcane to } \\
\text { sugar industry [48]. } \\
\text { - Govt. faced } \\
\text { resistance to ethanol } \\
\text { due to its high costs, } \\
\text { low efficiency, } \\
\text { concerns of } \\
\text { pollution, and land } \\
\text { use [70], [74]. }\end{array}$ & $\begin{array}{l}\text { - Ethanol subsidies } \\
\text { declined sharply } \\
\text { due to declining } \\
\text { political support, } \\
\text { ending of ethanol } \\
\text { policy initiative of } \\
\text { 1970s and many } \\
\text { supportive } \\
\text { governmental } \\
\text { institutions. New } \\
\text { subsidies benefitted } \\
\text { gasoline cars more } \\
\text { than pure ethanol } \\
\text { cars [48], [49], [72]. } \\
\text { - Decline in oil } \\
\text { prices reduced cost } \\
\text { competitiveness of } \\
\text { ethanol [48]-[50], } \\
\text { [53]. }\end{array}$ & $\begin{array}{l}\text { - Some resistance } \\
\text { due to water and } \\
\text { soil pollution and } \\
\text { deforestation } \\
\text { continued [74]. }\end{array}$ \\
\hline
\end{tabular}




\begin{tabular}{|c|c|c|c|}
\hline $\begin{array}{l}\text { all domestically } \\
\text { assembled LED } \\
\text { bulbs are imported. } \\
\text { - Absence of } \\
\text { linkages between } \\
\text { research capabilities } \\
\text { in universities \& } \\
\text { national labs and } \\
\text { LED industry and } \\
\text { market formation } \\
\text { policy. Initial } \\
\text { planned industry } \\
\text { collaboration in } \\
\text { 2007 did not } \\
\text { succeed at } \\
\text { commercialization } \\
\text { [22]. } \\
\text { - LED bulb quality } \\
\text { declined with costs } \\
\text { as a result of weak } \\
\text { enforcement of } \\
\text { technical standards } \\
\text { [22]. }\end{array}$ & \begin{tabular}{|l} 
targets and \\
incentives for RE, \\
but not PV-specific \\
{$[39],[42],[75]$,} \\
[79]. \\
• PV-specific \\
industry support \\
policies absent or \\
not effective [38]. \\
• High capital cost \\
of PV systems \\
relative to coal \\
electricity made PV \\
unattractive for \\
domestic market \\
[39]. \\
• High-entry barrier \\
into polysilicon and \\
equipment \\
manufacturing \\
delayed \\
manufacturing \\
expansion in these \\
segments [39], [44].
\end{tabular} & $\begin{array}{l}\text { disputes with } \\
\text { Germany and US } \\
\text { slow international } \\
\text { demand [41]. }\end{array}$ & $\begin{array}{l}- \text { Ethanol and oil } \\
\text { prices fixed by the } \\
\text { government led to } \\
\text { losses for industry } \\
\text { creating resistance } \\
\text { [53], [72]. } \\
\text { - Industry's } \\
\text { financial losses led } \\
\text { to resistance from } \\
\text { Petrobras, a key } \\
\text { player in ethanol } \\
\text { distribution [51], } \\
\text { [53]. } \\
\text { - Govt. R\&D } \\
\text { funding for ethanol } \\
\text { technologies } \\
\text { diminished [72]. }\end{array}$ \\
\hline
\end{tabular}




\section{References}

[1] R. Fouquet, "Path dependence in energy systems and economic development," Nat. Energy, vol. 1, p. 16098, Jul. 2016 https://doi.org/10.1038/nenergy.2016.98.

[2] K. C. Seto, S. J. Davis, R. B. Mitchell, E. C. Stokes, G. Unruh, and D. Ürge-Vorsatz, "Carbon Lock-In: Types, Causes, and Policy Implications," Annu. Rev. Environ. Resour., vol. 41, no. 1, pp. 425-452, Oct. 2016 https://doi.org/10.1146/annurev-environ-110615-085934.

[3] British Petroleum, "BP Statistical Review of World Energy 2019," 2019 https://www.bp.com/content/dam/bp/business-sites/en/global/corporate/pdfs/energyeconomics/statistical-review/bp-stats-review-2019-full-report.pdf.

[4] B.-A. Lundvall, K. J. Joseph, C. Chaminade, and J. Vang, "Handbook of Innovation Systems and Developing Countries: Building Domestic Capabilities in a Global Setting." Edward Elgar Publishing, Cheltenham, UK and Northampton, MA, USA, 2009.

[5] A. J. Wieczorek, "Sustainability transitions in developing countries: Major insights and their implications for research and policy," Environ. Sci. Policy, vol. 84, pp. 204-216, 2018.

[6] D. M. Kammen and A. Jacobson, "Solar Innovation and Market Feedback: Solar Photovoltaics in Rural Kenya," in Energy Technology Innovation, Cambridge University Press, 2014, p. 244.

[7] H. A. Romijn and M. C. J. Caniëls, "Pathways of technological change in developing countries: review and new agenda," Dev. Policy Rev., vol. 29, no. 3, pp. 359-380, 2011.

[8] J. Gosens, Y. Lu, and L. Coenen, "The role of transnational dimensions in emerging economy 'Technological Innovation Systems' for clean-tech,” J. Clean. Prod., vol. 86, pp. 378-388, 2015 http://www.sciencedirect.com/science/article/pii/S0959652614008518.

[9] World Bank, "World Bank Country and Lending Groups - World Bank Data Help Desk." [Online]. Available: https://datahelpdesk.worldbank.org/knowledgebase/articles/906519world-bank-country-and-lending-groups. [Accessed: 02-Aug-2019]

https://datahelpdesk.worldbank.org/knowledgebase/articles/906519-world-bank-country-andlending-groups.

[10] M. P. Hekkert, R. A. A. Suurs, S. O. Negro, S. Kuhlmann, and R. E. H. M. Smits, "Functions of innovation systems: A new approach for analysing technological change," Technol. Forecast. Soc. Change, vol. 74, no. 4, pp. 413-432, 2007 http://www.sciencedirect.com/science/article/pii/S0040162506000564.

[11] F. W. Geels, "Technological transitions as evolutionary reconfiguration processes: A multilevel perspective and a case-study," Res. Policy, vol. 31, no. 8-9, pp. 1257-1274, 2002.

[12] J. Markard, R. Raven, and B. Truffer, "Sustainability transitions: An emerging field of research and its prospects," Res. Policy, vol. 41, no. 6, pp. 955-967, 2012 http://www.sciencedirect.com/science/article/pii/S004873331200056X.

[13] J. Köhler et al., "An agenda for sustainability transitions research: State of the art and future directions," Environ. Innov. Soc. Transitions, vol. 31, no. January, pp. 1-32, 2019 https://doi.org/10.1016/j.eist.2019.01.004.

[14] D. Loorbach, N. Frantzeskaki, and F. Avelino, "Sustainability Transitions Research: Transforming Science and Practice for Societal Change," Annu. Rev. Environ. Resour., vol. 42, pp. 599-626, 2017.

[15] A. Bergek, S. Jacobsson, B. Carlsson, S. Lindmark, and A. Rickne, "Analyzing the functional dynamics of technological innovation systems: A scheme of analysis," Res. Policy, vol. 37, no. 3, pp. 407-429, 2008 http://www.sciencedirect.com/science/article/pii/S004873330700248X. 
[16] B. Carlsson and R. Stankiewicz, "On the nature, function and composition of technological systems,” J. Evol. Econ., vol. 1, no. 2, pp. 93-118, 1991.

[17] K. M. Weber and B. Truffer, "Moving innovation systems research to the next level: Towards an integrative agenda," Oxford Rev. Econ. Policy, vol. 33, no. 1, pp. 101-121, 2017.

[18] P. Huang, S. O. Negro, M. P. Hekkert, and K. Bi, "How China became a leader in solar PV: An innovation system analysis," Renew. Sustain. Energy Rev., vol. 64, no. 145, pp. 777-789, 2016.

[19] F. Alkemade, C. Kleinschmidt, and M. P. Hekkert, Analysing emerging innovation systems: A functions approach to foresight, vol. 3. 2007.

[20] R. Quitzow, "Dynamics of a policy-driven market: The co-evolution of technological innovation systems for solar photovoltaics in China and Germany," Environ. Innov. Soc. Transitions, vol. 17, p. 23, 2015 https://ac.els-cdn.com/S2210422414000914/1-s2.0S2210422414000914-main.pdf? tid=0e716173-21dd-4d61-a681143b6ed5194e\&acdnat=1551766948_dcb6f552f25ec3e5cc1c61ff20688fb5.

[21] V. Vasseur, L. M. Kamp, and S. O. Negro, "A comparative analysis of Photovoltaic Technological Innovation Systems including international dimensions: the cases of Japan and The Netherlands," J. Clean. Prod., vol. 48, pp. 200-210, 2013 http://www.sciencedirect.com/science/article/pii/S095965261300022X.

[22] A. S. Kamat, R. Khosla, and V. Narayanamurti, "Illuminating homes with LEDs in India: Rapid market creation towards low-carbon technology transition in a developing country," Energy Res. Soc. Sci., vol. 66, no. 101488, 2020.

[23] X. Bai et al., "Six research priorities for cities and climate change," Nature, vol. 255, pp. 23$25,2018$.

[24] U. E. Hansen, I. Nygaard, H. Romijn, A. Wieczorek, L. M. Kamp, and L. Klerkx, "Sustainability transitions in developing countries: Stocktaking, new contributions and a research agenda,” Environ. Sci. Policy, vol. 84, no. December 2017, pp. 198-203, 2018.

[25] F. Malerba and R. R. Nelson, Economic development as a learning process: Variation across sectoral systems. Edward Elgar Publishing, 2012.

[26] X. Fu, C. Pietrobelli, and L. Soete, "The Role of Foreign Technology and Indigenous Innovation in the Emerging Economies: Technological Change and Catching-up," World Dev., vol. 39, no. 7, pp. 1204-1212, 2011.

[27] T. Altenburg, H. Schmitz, and A. Stamm, "Breakthrough? China's and India's Transition from Production to Innovation," World Dev., vol. 36, no. 2, pp. 325-344, 2008.

[28] R. Kempener, L. Diaz Anadon, K. S. Gallagher, and K. Jiang, "Energy RD\&D investments in the major emerging economies and the United States," Energy Technol. Innov. Learn. from Hist. Successes Fail., p. 309, 2013.

[29] V. Govindarajan and R. Ramamurti, "Reverse Innovation, Emerging Markets, and Global Strategy,” Glob. Strateg. J., vol. 1, pp. 191-205, 2011.

[30] “UIS.Stat.” UNESCO Institute of Statistics http://data.uis.unesco.org/.

[31] Bureau of Economic Analysis (BEA), "Activities of U.S. Multinational Enterprises: 2016," $2018 \mathrm{https} / /$ www.bea.gov/system/files/2018-11/omne0818.pdf.

[32] Electric Lamp and Component Manufacturers' Association of India (ELCOMA), "Lighting Industry Data 2018-19.” [Online]. Available: http://www.elcomaindia.com/wpcontent/uploads/Lighting-Data-2018-01.05.2019.pdf. [Accessed: 03-Aug-2019] http://www.elcomaindia.com/wp-content/uploads/Lighting-Data-2018-01.05.2019.pdf. 
[33] IEA, "World Energy Outlook 2019,” 2019 https://webstore.iea.org/download/summary/2467? fileName=Japanese-Summary-WEO2019.pdf.

[34] A. Chunekar, S. Mulay, and M. Kelkar, "Understanding the impacts of India's LED bulb programme, "UJALA,"” 2017 http://www.prayaspune.org/peg/publications/item/354understanding-the-impacts-of-india-s-led-bulb-programme-ujala.html.

[35] A. Kumar, S. K. Jain, and N. K. Bansal, "Disseminating energy-efficient technologies: A case study of compact fluorescent lamps (CFLs) in India," Energy Policy, vol. 31, no. 3, pp. 259272, 2003.

[36] IEA-PVPS, "Trends in Photovoltaic Applications (annual reports from 2013 to 2018)."

[37] IEA-PVPS, "National Survey Reports of Photovoltaic Applications in United States of America (annual reports from 2005 to 2017); National Survey Reports of Photovoltaic Applications in China (annual reports from 2011 to 2016); National Survey Reports of Photovoltaic" http://www.iea-pvps.org/?id=93.

[38] C. Binz and L. D. Anadon, "Unrelated diversification in latecomer contexts: Emergence of the Chinese solar photovoltaics industry," Environ. Innov. Soc. Transitions, vol. 28, no. March, pp. 14-34, 2018.

[39] A. de la Tour, M. Glachant, and Y. Ménière, "Innovation and international technology transfer: The case of the Chinese photovoltaic industry," Energy Policy, vol. 39, no. 2, pp. 761-770, 2011.

[40] T. Grau, M. Huo, and K. Neuhoff, "Survey of photovoltaic industry and policy in Germany and China," Energy Policy, vol. 51, pp. 20-37, 2012 http://dx.doi.org/10.1016/j.enpol.2012.03.082.

[41] E. G. Hansen, F. Ludeke-Freund, X. I. Quan, and J. West, "Cross-National Complementarity of Technology Push, Demand Pull, and Manufacturing Push Policies: The Case of Photovoltaics," IEEE Trans. Eng. Manag., vol. 66, no. 3, pp. 381-397, 2019.

[42] Z. Qiang, S. Honghang, L. Yanxi, X. Yurui, and S. Jun, "China's solar photovoltaic policy: An analysis based on policy instruments," Appl. Energy, vol. 129, pp. 308-319, 2014.

[43] L. T. Lam, L. Branstetter, and I. L. Azevedo, "A sunny future: expert elicitation of China's solar photovoltaic technologies," Environ. Res. Lett, vol. 13, no. 034038, p. 034038, 2018 https://doi.org/10.1088/1748-9326/aaab70.

[44] L. qun Liu, Z. xin Wang, H. qiang Zhang, and Y. cheng Xue, "Solar energy development in China - A review," Renew. Sustain. Energy Rev., vol. 14, pp. 301-311, 2010.

[45] S. Honghang, Z. Qiang, W. Yibo, Y. Qiang, and S. Jun, "China's solar photovoltaic industry development: The status quo, problems and approaches," Appl. Energy, vol. 118, pp. 221-230, 2014.

[46] IEA, "Snapshot on global photovoltaic markets," $2015 \mathrm{http}: / /$ www.ieapvps.org/fileadmin/dam/public/report/PICS/IEA-PVPS_-_A_Snapshot_of_Global_PV__1992-2015__Final_2_02.pdf.

[47] IEA-ETSAP and IRENA, "Production of Liquid Biofuels: Technology Brief," 2013 https://www.irena.org/DocumentDownloads/Publications/IRENA-ETSAP Tech Brief P10 Production_of_Liquid Biofuels.pdf.

[48] S. L. Stattman, O. Hospes, and A. P. J. Mol, "Governing biofuels in Brazil: A comparison of ethanol and biodiesel policies," Energy Policy, vol. 61, pp. 22-30, 2013.

[49] D. Meyer, L. Mytelka, R. Press, E. L. Dall'Oglio, P. T. de Sousa Jr, and A. Grubler, "Brazilian ethanol: Unpacking a success story of energy technology innovation," in Energy Technology 
Innovation, Cambridge University Press, 2014.

[50] J. Goldemberg, "The Brazilian biofuels industry," Biotechnol. Biofuels, vol. 1, no. 6, 2008.

[51] J. A. P. Rico, S. S. P. Mercedes, and I. L. Sauer, "Genesis and consolidation of the Brazilian bioethanol: A review of policies and incentive mechanisms," Renew. Sustain. Energy Rev., vol. 14, no. 7, pp. 1874-1887, 2010.

[52] ANFAVEA, "Brazilian Automotive Industry Yearbook," 2019 http://www.virapagina.com.br/anfavea2019/.

[53] F. Rosillo-Calle and L. A. B. Cortez, "Towards proalcool II - A review of the Brazilian bioethanol programme," Biomass and Bioenergy, vol. 14, no. 2, pp. 115-124, 1998.

[54] J. Goldemberg, "Ethanol for a sustainable energy future," Science (80-. )., vol. 315, no. 5813, pp. 808-810, 2007.

[55] A. J. Wieczorek and M. P. Hekkert, "Systemic instruments for systemic innovation problems: A framework for policy makers and innovation scholars," Sci. Public Policy, vol. 39, pp. 7487, 2012.

[56] G. Kavlak, J. McNerney, and J. E. Trancik, "Evaluating the causes of cost reduction in photovoltaic modules," Energy Policy, vol. 123, no. August 2017, pp. 700-710, 2018 https://doi.org/10.1016/j.enpol.2018.08.015.

[57] G. F. Nemet, "Beyond the learning curve: factors influencing cost reductions in photovoltaics," Energy Policy, vol. 34, no. 17, pp. 3218-3232, 2006.

[58] A. Prag, D. Röttgers, and I. Scherrer, "State-Owned Enterprises and the Low-Carbon

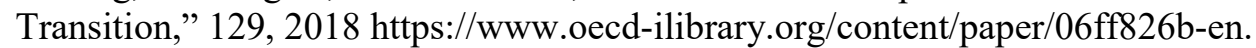

[59] H. Z. A. van der Loos, S. O. Negro, and M. P. Hekkert, "International markets and technological innovation systems: The case of offshore wind," Environ. Innov. Soc. Transitions, vol. 34, no. March 2019, pp. 121-138, 2020 https://doi.org/10.1016/j.eist.2019.12.006.

[60] K. S. Gallagher, "Limits to leapfrogging in energy technologies? Evidence from the Chinese automobile industry," Energy Policy, vol. 34, no. 4, pp. 383-394, 2006.

[61] R. Lema and A. Lema, "Technology transfer? The rise of China and India in green technology sectors," Innov. Dev., vol. 2, no. 1, pp. 23-44, 2012.

[62] A. Grubler et al., "Policies for the Energy Technology Innovation System (ETIS)," in Global Energy Assessment, 2012, pp. 1665-1744 http://www.iiasa.ac.at/web/home/research/FlagshipProjects/Global-Energy-Assessment/GEA_Chapter24_ETIS_hires.pdf.

[63] J. Markard, "The next phase of the energy transition and its implications for research and policy," Nat. Energy, vol. 3, pp. 628-633, 2018.

[64] V. Narayanamurti and T. B. Odumosu, Cycles of Invention and Discovery: Rethinking the Endless Frontier. Harvard University Press, 2016.

[65] L. D. Anadón, "Missions-oriented RD\&D institutions in energy between 2000 and 2010: A comparative analysis of China, the United Kingdom, and the United States," Res. Policy, vol. 41, no. 10, pp. 1742-1756, 2012 http://dx.doi.org/10.1016/j.respol.2012.02.015.

[66] B. K. Sovacool and M. Martiskainen, "Hot transformations: Governing rapid and deep household heating transitions in China, Denmark, Finland and the United Kingdom," Energy Policy, vol. 139, p. 111330, 2020.

[67] T. S. Schmidt and J. Huenteler, "Anticipating industry localization effects of clean technology 
deployment policies in developing countries," Glob. Environ. Chang., vol. 38, pp. 8-20, 2016 http://dx.doi.org/10.1016/j.gloenvcha.2016.02.005.

[68] E. Traut, C. Hendrickson, E. Klampfl, Y. Liu, and J. J. Michalek, "Optimal design and allocation of electrified vehicles and dedicated charging infrastructure for minimum life cycle greenhouse gas emissions and cost," Energy Policy, vol. 51, pp. 524-534, 2012 http://dx.doi.org/10.1016/j.enpol.2012.08.061.

[69] F. Dincer, "The analysis on photovoltaic electricity generation status, potential and policies of the leading countries in solar energy," Renew. Sustain. Energy Rev., vol. 15, pp. 713-720, 2011.

[70] A. E. Wheals, L. C. Basso, D. M. G. Alves, and H. V. Amorim, "Fuel ethanol after 25 years," Trends Biotechnol., vol. 17, no. 12, pp. 482-487, 1999.

[71] J. R. Moreira and J. Goldemberg, "The alcohol program," Energy Policy, vol. 27, pp. 229-245, 1999.

[72] J. D. van den Wall Bake, M. Junginger, A. Faaij, T. Poot, and A. Walter, "Explaining the experience curve: Cost reductions of Brazilian ethanol from sugarcane," Biomass and Bioenergy, vol. 33, pp. 644-658, 2009.

[73] C. Y. Wu and J. A. Mathews, "Knowledge flows in the solar photovoltaic industry: Insights from patenting by Taiwan, Korea, and China," Res. Policy, vol. 41, no. 3, pp. 524-540, 2012 http://dx.doi.org/10.1016/j.respol.2011.10.007.

[74] L. A. Martinelli and S. Filoso, "Expansion of Sugarcane Ethanol Production in Brazil: Environmental and Social Challenges," Ecol. Appl., vol. 18, no. 4, pp. 885-898, 2008.

[75] X. Yang, Y. Song, G. Wang, and W. Wang, "A comprehensive review on the development of sustainable energy strategy and implementation in China," IEEE Trans. Sustain. Energy, vol. 1, no. 2, pp. 57-65, 2010.

[76] J. Goldemberg, S. T. Coelho, and P. Guardabassi, "The sustainability of ethanol production from sugarcane," Energy Policy, vol. 36, pp. 2086-2097, 2008.

[77] Ministry of Power (India), "National Ujala Dashboard." [Online]. Available: http://www.ujala.gov.in/. [Accessed: 01-Jul-2020] http://www.ujala.gov.in/.

[78] Ministry of Communications and Information Technology (India), “Annual Report 2015-16," 2016.

[79] R. Long, W. Cui, and Q. Li, "The evolution and effect evaluation of photovoltaic industry policy in China," Sustainability, vol. 9, p. 2147, 2017. 
i We refer to low- and middle-income countries [9] as 'developing countries' and the ten largest economies among them (larger than many developed (high-income) countries) as 'emerging economies'. In emerging economies, characteristics of developing and developed countries co-exist. For example, universities and national labs which have developed world-class research capabilities in selected science and engineering areas, with restrictions due to financing, infrastructure, and institutions which hinder scaling up of technologies.

ii Since India's economic liberalization in 1991, the government is divesting from many industries, including automobile manufacturing. 